\title{
A Systems Perspective on the Natural Resources Framework: comment on Hearnshaw et al.
}

\section{The Natural Resources Framework is a new approach}

to policy advice developed by the multi-agency natural

resource sector in New Zealand. This framework has been

implemented with some success, but also some teething

problems. The framework is a 'systems' approach to

understanding the interaction between the many actors

in the natural resource management system, and as such

could benefit from insights and lessons from the systems

sciences. This article is a rejoinder to Hearnshaw et

al. (2014), and presents three suggestions for how the

framework could be improved based on literature from

the fields of system dynamics and systems thinking.

\section{Introduction}

In 2012 the performance of the Ministry for the Environment was independently reviewed, using the Performance Improvement Framework (State Services Commission, 2012). Among a long list of recommendations, the final report recommended that the ministry develop a 'multi-disciplinary analytic framework' for understanding complex trade-offs inherent in the public management of natural resources. In response, the ministry led the development of the Natural Resources Framework (Ministry for the Environment, 2013). The framework consists of six steps: four analytical steps in between two process steps. The six steps are: Identify; Reveal; Establish; Assess; Integrate; Advise (see detailed description
This article is written from the perspective of a participant in two large projects that used the Natural Resources Framework: one collaborative initiative involving seven agencies in the natural resources sector (Cavana et al., 2014), and a second project conducted within the Ministry for the Environment. In both of these projects, the framework was useful in revealing new insights and helping participants to understand connections, but applying the framework also created several challenges. Many of these challenges were reminiscent of challenges faced, and subsequently overcome, in the fields of system dynamics and systems thinking. in Hearnshaw et al., 2014).
Rodney Scott is a PhD student at the University of Queensland. He has recently submitted his thesis, 'Group model building and mental model change', which includes discussion on the use of participatory system dynamics methods in state sector decision-making.
This article is likely to be of interest to two main audiences: to the authors of the framework, in refining their methods and the associated guidance documents for how to use the framework; and to public servants and other practitioners looking to appropriate the framework to fit their needs.

The following discussion consists of five sections. First, the systems sciences are introduced, and an argument is put forward to justify the view that the framework is a systemic approach. Then, three sections describe important lessons from the systems sciences on how to apply systemic approaches: focusing on problems rather than systems; having clarity on desired outcomes; and using the framework to answer questions that start with 'why' rather than 'how'. Finally, a short conclusion describes how these recommendations could be accommodated within the framework and identifies areas for further research.

Why the Natural Resources Framework is a systemic approach

A system consists of a collection of interrelated parts that exhibit behaviour as a product of their interaction (von Bertalanffy, 1952). System dynamics is an approach to understanding the behaviour of systems over time through the use of modelling techniques (Forrester, 1961). The Natural Resources Framework follows very similar steps as those used in system dynamics modelling, as shown in Table 1.

Systems thinking is a management technique consisting of a visual diagramming language for understanding social organisations (Senge, 1990). It was developed as an offshoot of system dynamics, for situations where formal 
Table 1: Process steps in system dynamics modelling and the Natural Resources Framework

\begin{tabular}{ll}
\hline System dynamics (Sterman, 2000) & $\begin{array}{l}\text { Natural Resources Framework (Hearnshaw et } \\
\text { al., 2014) }\end{array}$ \\
\hline $\begin{array}{l}\text { Identify relevant systemic structures and } \\
\text { variables (stocks and flows) }\end{array}$ & Reveal the important variables in the system \\
\hline $\begin{array}{l}\text { Create a model that represents the dynamic } \\
\text { behaviour of the system }\end{array}$ & $\begin{array}{l}\text { Establish the dynamics and behaviours of the } \\
\text { system }\end{array}$ \\
\hline Simulate and compare multiple policy options & Assess multiple policy options \\
\hline $\begin{array}{l}\text { Recommend actions for improved system } \\
\text { performance }\end{array}$ & $\begin{array}{l}\text { Integrate these options into an intervention } \\
\text { plan }\end{array}$ \\
\hline
\end{tabular}

Table 2: Conceptual stages in systemic and analytic thought

\begin{tabular}{lll}
\hline $\begin{array}{l}\text { Systemic approach (Ackoff, } \\
\text { 1994) }\end{array}$ & $\begin{array}{l}\text { Natural Resources } \\
\text { Framework (Hearnshaw et } \\
\text { al., 2014) }\end{array}$ & $\begin{array}{l}\text { Analytic approach (Ackoff, } \\
\text { 1994) }\end{array}$ \\
\hline $\begin{array}{l}\text { Of what is the thing I am } \\
\text { studying a part? }\end{array}$ & $\begin{array}{l}\text { Describe the containing } \\
\text { environment }\end{array}$ & $\begin{array}{l}\text { What are the component } \\
\text { parts of the thing that I am } \\
\text { studying? }\end{array}$ \\
\hline $\begin{array}{l}\text { What are the functions and } \\
\text { behaviours of the containing } \\
\text { system? }\end{array}$ & $\begin{array}{l}\text { Reveal the interrelationships } \\
\text { between natural resources } \\
\text { and people }\end{array}$ & $\begin{array}{l}\text { What are the functions of the } \\
\text { parts? }\end{array}$ \\
\hline $\begin{array}{l}\text { What is the contribution of } \\
\text { the object of study to the } \\
\text { behaviours of the containing } \\
\text { system? }\end{array}$ & $\begin{array}{l}\text { Analyse the behavioural } \\
\text { drivers that people face } \\
\text { and the effect on collective } \\
\text { behaviour }\end{array}$ & $\begin{array}{l}\text { Can knowledge of the } \\
\text { parts be aggregated to an } \\
\text { understanding of the whole? }\end{array}$ \\
\hline
\end{tabular}

quantitative modelling was not possible or not required (Coyle, 2000). Systems thinking has been contrasted with analytic thought (Ackoff, 1994; see Table 2); the Natural Resources Framework uses a cognitive perspective that is much more closely aligned to a systemic than to an analytic approach.

As the name suggests, policy analysis typically follows an analytic approach in which complicated problems are reduced into simpler parts. At the launch of the Natural Resources Framework, some audience members (both from within the Ministry for the Environment and from the broader natural resources sector) were unsure how the framework differed from traditional policy approaches. Tables 1 and 2 clearly identify the Natural Resources Framework as a systemic approach in contrast to traditional policy analysis, demonstrating the separate and distinct contribution of the framework. The original authors indirectly acknowledge the systemic nature of the Natural Resources Framework by using the words 'system', 'systems' and 'systemic' no fewer than 41 times in its description (Hearnshaw et al., 2014). One of the projects described made use of a tool from system dynamics (the causal loop diagram) to complete the Reveal phase, demonstrating the parallel process steps (and substitutability) of the different approaches (Cavana et al., 2014).

Systems thinking and system dynamics are both established academic fields with significant research literature. Each has its Society for the System Sciences, and the System Dynamics Society) and its own peer-reviewed journal (Systems Research and Behavioural Science and the System Dynamics Review respectively). In applying systemic approaches, each field has encountered challenges and set-backs (see, for example, Forrester, 1993; Eskinasi and Fokkema, 2006; Größler, 2007), and overcome these to demonstrate significant positive results (Scott, Cavana and Cameron, 2013, 2014a). Through this experience, each field has documented important lessons about how to apply systemic methods effectively (Martinez-Moyano and Richardson, 2013; Scott, Cavana and Cameron, 2014b). The following sections describe three such lessons, and their relevance and application to improving the effectiveness of the framework. own professional society (International
Use systemic approaches to understand problems, not systems

Perhaps counterintuitively, system dynamics modelling is a process for understanding problems, not for understanding systems (Radzicki, 2010). This is because attempting to model systems typically results in excessively large models that are difficult to understand (Sterman, 2000). The basic mantra 'problems, not systems' is part of the most basic instruction of both systems thinking (Senge, 1990) and system dynamics (Saeed, 1998).

The Identify stage of the framework asks its users to clarify scope, but not to define the problem. This stage is described as procedural rather than analytic. In both projects discussed in this article the process quickly jumped to the Reveal stage. Both projects defined their purpose as understanding the natural resource management system (and acknowledged that they may have been stretching the applicability of the framework by using it in this way). During the process there were frequent discussions about whether information was relevant, and the level of detail required. The cross-agency project included detailed descriptions of some elements of the system and only the broadest outline of others, with no clear rationale for the distinction (Cavana et al., 2014). In the Ministry for the Environment project, some participants collected information about social norms, while others were more interested in quantitative data about resource-based industrial activity. The project team was forced to repeat the Reveal stage several times as the focus and level of detail was redefined, resulting in delays of several months. By defining their purpose as understanding a system, they had no criteria for determining materiality or relevance of information within that system.

In contrast, if the projects had been oriented around addressing a problem, then the scope could have been assessed as the variables most relevant to understanding the dynamic behaviour of that problem (Maani and Cavana, 2003).

Lessons from systems sciences suggest that it is not sufficient to define scope in terms of the system being investigated 
(Radzicki, 2010). 'Scope' typically specifies the outer boundaries, but not the materiality of information within those boundaries (see Ulrich, 2002; Cabrera, 2006). This suggests that the Identify stage should be amended from a focus on scope to one that includes problem definition. This is also likely to require elevation of Identify from a procedural stage to an analytic one.

\section{Be very clear on the outcomes sought}

A related challenge is the clarity of desired outcomes. When exploring the behaviour of systems, a problem is defined as the gap between the situation we desire and the situation we perceive (Sterman, 2001). A robust problem definition includes description of why the current situation is not optimal: that is, the outcomes sought, and how the current state differs from those aspirations.

The Natural Resources Framework includes a consideration of outcomes and trade-offs in the third and fourth analytic stages (Integrate and Assess). This is used as a basis for determining which policy option is preferable, and is too late to inform and guide the Reveal and Establish phases.

In the Ministry for the Environment project, the lack of clear outcomes hampered information gathering in the Reveal stage. Many project meetings involved lengthy discussions to clarify and then re-litigate the outcomes being investigated. For example, it was unclear if the goals of the natural resource management system were maximising social, economic and environmental outcomes, or whether procedural and distributive elements were also important. This was the subject of considerable debate and caused delay. If procedural and distributive elements were important goals, then the Reveal stage needed to gather information on these elements. The Establish phase would need to understand the incentives and behaviours that had an impact on these elements. If these elements were included and later deemed irrelevant, then the time used to investigate this relationship would have been unproductive. If they had been excluded and later deemed important, then the Reveal and Establish phases
Figure 1: Directions of inquiry

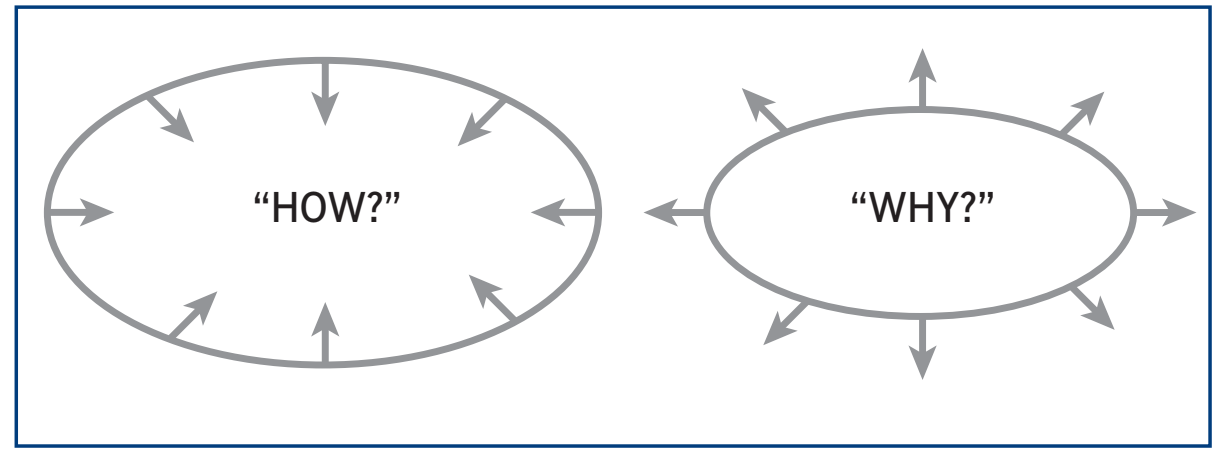

would need to be repeated to incorporate these relationships.

When the Ministry for the Environment had a follow-up Performance Improvement Framework review in 2014, the reviewers applauded the development of the framework, but stated that the ministry needed to work with the broader natural resources sector to specify explicit and measurable environmental outcomes (State Services Commission, 2014). A systemic approach requires the explicit identification of desired outcomes as part of a problem definition, and prior to mapping the system (Andersen, Richardson and Vennix, 1997). The Natural Resources Framework would be strengthened and streamlined by explicitly establishing the desired outcomes before attempting to understand the dynamics and linkages that contribute to those outcomes.

\section{Use systemic approaches to understand} 'why' questions rather than 'how' questions. 'How' (mechanism) and 'why' (function and history) are complementary categories of inquiry for understanding behaviour (Tinbergen, 1963; Hladký and Havlíček, 2013). Within the field of systems thinking, systemic approaches are thought to be better suited to understanding questions on function and history, i.e. those that begin with 'why' (Ackoff, 1993, 1994). Reductionist approaches are better suited to questions of mechanism, those that begin with 'how'. Answering 'how' questions requires knowledge about the thing being studied. Answering 'why' questions requires an understanding about the containing whole (Ackoff, 1999; see Figure 1).

'How' questions look within the thing studied; 'Why' questions look backwards and outwards to understand the dynamics of the containing system over time.

Both projects discussed in this article explored the question, 'How does the natural resource management system work?' This is a question of mechanism. This question could be answered by an analytic/reductionist process that looked within the management system. An analyst could divide the natural resource management regime into its component parts, describe those parts, and then aggregate that knowledge into a description of the whole.

Conversely, a 'why' question - e.g. 'Why do air quality problems persist in some areas?' - is well suited to a systemic approach. This would require looking more broadly than the air quality management system, and at the social, economic and biophysical context of the problem. It would require understanding the incentives on behaviour of the different parties. The resultant understanding could lead to policy interventions that better supported the desired behaviours.

The Natural Resources Framework may be successful in explaining how things work, but it is not clear why this would be more effective than traditional policy approaches. Literature on systemic approaches suggests that the framework would be most applicable for exploring why certain behaviours or suboptimal outcomes occur.

\section{Conclusion}

The Natural Resources Framework is an important development in creating more coherent and resilient natural resource policy. As a new tool, it represents an admirable first attempt at a systemic approach to policy development. As it is applied in practice, there are opportunities 
to augment and refine its features. The literature on systemic approaches suggests that refinements should be made to both how and when the framework is used.

First, greater effort must be directed at a clear problem definition with explicit goals. Systems literature suggests that working on systems (rather than problems) will doom the framework from the beginning. The preparatory stage of the framework (Identify) needs clarifying and emphasising to prevent wasted effort in the Reveal and Establish phases. In developing the framework, the Identify phase was apparently the subject of considerable debate, and eventually left open to encourage the framework to be used for a wide range of purposes (personal communication, James Palmer, August 2014). It may be useful to review this decision in light of early experiences with using the framework.

Second, the Natural Resources Framework is a tool, but not the only tool, for policy development. In its eagerness to apply the new framework, the Ministry for the Environment has applied the framework to two contexts to which it does not appear to be well-suited. The Natural Resources Framework needs to be positioned as augmenting our policy analysis toolkit, with clear guidance provided on when it is and is not the most appropriate tool. The systems literature suggests that it will be most useful for problems that require an understanding of why certain behaviours are exhibited, not just how they play out.

This article has been prepared on the basis of the author's experience with two projects, and considerable experience in using systemic approaches in other contexts. The conclusions are therefore early impressions of the journey of implementing the framework. Further research is required on subsequent application of the framework, in order that its use may be further refined.

\section{References}

Ackoff, R.L. (1993) 'From mechanistic to social systemic thinking', Proceedings of the 1993 Conference on Systems Thinking in Action, Cambridge: Pegasus Communication

Ackoff, R.L. (1994) 'Systems thinking and thinking systems', System Dynamics Review, 10, pp.175-88

Ackoff, R.L. (1999) Ackoff's Best: his classic writings on management, New York: Wiley

Andersen, D.F., G.P. Richardson and J.A.M. Vennix (1997) 'Group model building: adding more science to the craft', System Dynamics Review, 13 (2), pp.187-203

Cabrera, D. (2006) 'Boundary critique: a minimal concept theory of systems thinking', Proceedings of the 50th Annual Conference of the International Society for the Systems Sciences, Hull: International Society for the Systems Sciences

Cavana, R.Y., T. Smith, R.J. Scott and S. O'Connor (2014) 'Causal mapping of the New Zealand natural resources sector system: a group model building approach', Proceedings on the 32nd International Conference of the System Dynamics Society, Chestnut Hill: System Dynamics Society

Coyle, G. (2000) 'Qualitative and quantitative modelling in system dynamics: some research questions', System Dynamics Review, 16 (3), pp.225-44

Eskinasi, M. and E. Fokkema (2006) 'Lessons learned from unsuccessful modelling interventions', Systems Research and Behavioral Science, 23 (4), pp.483-92

Forrester, J.W. (1961) Industrial dynamics, Cambridge: Productivity Press

Forrester, J.W. (1991) 'System dynamics and the lessons of 35 years', in K.B. De Greene (ed.), The Systemic Basis of Policy Making in the 1990s, Boston: Sloan School of Management

Größler, A. (2007) 'System dynamics projects that failed to make an impact', System Dynamics Review, 23 (4), pp.437-52

Hearnshaw, E., T. Smith, J. Carpenter, J. Pennington, J. Mowbray, R. Maplesden and J. Palmer (2014) 'Stewardship and the Natural Resources Framework', Policy Quarterly, 10 (1), pp.35-44

Hladký, V. and J. Havlíček (2013) 'Was Tinbergen an Aristotelian? Comparison of Tinbergen's four whys and Aristotle's four causes', Human Ethology Bulletin, 28 (4), pp.3-11

Maani, K.E. and R.Y. Cavana (2000) Systems Thinking and Modelling: understanding change and complexity, Brisbane: Pearson Education

Ministry for the Environment (2013) Natural Resources Framework, accessed at http://nrs.mfe.govt.nz/content/natural-resources-framework
Ministry for the Environment (2014) About the Natural Resources Sector, accessed at http://nrs.mfe.govt.nz/content/about-natural-resourcessector

Martinez-Moyano, I.J. and G.P. Richardson (2013) 'Best practices in system dynamics modeling', System Dynamics Review, 29 (2), pp.102-23

Radzicki, M.J. (2010) 'Was Eichner a system dynamicist?', in M. Lavoie, L. Rochon and M. Sccareccia (eds), Money and Macrodynamics: Alfred Eichner and post-Keynesian economics, New York: Sharpe

Saeed, K. (1998) Defining a Problem or Constructing a Reference Mode, working paper, Worcester: Worcester Polytechnic Institute

Scott, R.J., R.Y. Cavana and D. Cameron (2013) 'Evaluating immediate and long-term impacts of qualitative group model building workshops on participants' mental models', System Dynamics Review, 29 (4) pp.216-36

Scott, R.J., R.Y. Cavana and D. Cameron (2014a) 'Interpersonal success factors for strategy implementation: a case study using group model building', Journal of the Operational Research Society, DOI:10.1057/ jors.2014.70

Scott, R.J., R.Y. Cavana and D. Cameron (2014b) 'Mechanisms for understanding mental model change in group model building', Systems Research and Behavioral Science, DOI:10.1002/sres.2303

Senge, P. (1990) The Fifth Discipline: the art and practice of learning, New York: Doubleday

State Services Commission (2012) Performance Improvement Framework: formal review of Manatū Mō te Taiao Ministry for the Environment, accessed at http://www.ssc.govt.nz/sites/all/files/pif-mfereview-dec12.pdf

State Services Commission (2014) Performance Improvement Framework: follow-up review of Manatū Mō te Taiao Ministry for the Environment, accessed at http://www.mfe.govt.nz/publications/about/ follow-up-pif-review-aug14/follow-up-pif-aug14.pdf

Sterman, .JD. (2000) Business Dynamics: systems thinking and modeling for a complex world, Boston: McGraw-Hill

Sterman, J.D. (2001) 'System dynamics modeling: tools for learning in a complex world', California Management Review, 43 (4), pp.8-25

Tinbergen, N. (1963) 'On aims and methods of ethology', Zeitschrift für Tierpsychologie, 20, pp.410-33

Ulrich, W. (2002) 'Boundary critique', in H.G. Daellenbach and R.L. Flood (eds), The Informed Student Guide to Management Science, London: Thomson Learning

Von Bertalanffy, L. (1952) Problems of Life, New York: Wiley 